\title{
LIGHT ORGAN ANOMALIES IN THREE SPECIES OF MYCTOPHID FISHES (ACTINOPTERYGII: MYCTOPHIFORMES: MYCTOPHIDAE) FROM THE PACIFIC COAST OF MEXICO
}

\author{
José DE LA CRUZ-AGÜERO* \\ Instituto Politécnico Nacional-Centro Interdisciplinario de Ciencias Marinas, \\ Departamento de Pesquerías y Biología Marina, Colección Ictiológica, La Paz, Baja California Sur, México
}

De La Cruz-Agüero J. 2016. Light organ anomalies in three species of myctophid fishes (Actinopterygii: Myctophiformes: Myctophidae) from the Pacific coast of Mexico. Acta Ichthyol. Piscat. 46 (3): 247-250.

\begin{abstract}
Despite numerous anomalies that have been reported for many species of fishes, records on deep-water species are scarce and apparently very rare for luminescent organs (i.e., photophores). In presently reported study, we described and illustrated anomalies in the number and placement of primary light organs in three lanternfish species: the Mexican lampfish, Triphoturus mexicanus (Gilbert, 1890); the highseas lampfish, Triphoturus nigrescens (Brauer, 1904); and the popeye lampfish, Bolinichthys longipes (Brauer, 1906), collected off the Pacific coast of Mexico.
\end{abstract}

Keywords: extraneous photophores, lanternfishes, Baja California Sur

Nearly five percent of the living species of rayfinned fishes have some type of light organs (Davis et al. 2016, Nelson et al. 2016). From these fishes, the family Myctophidae or lanternfishes, include more than two hundred fifty species (Froese and Pauly 2016), many of which live in the mid-water zone of the tropical and subtropical temperate oceans. More than half of these species, about one hundred fifty, inhabit the eastern Pacific Ocean (Wisner 1976).

Several morphological characters are helpful in distinguishing lanternfish genera and species, but their primary light organs (e.g., the lateral and ventrolateral photophore series) and their number, arrangement, and size are by far the most useful. However, in some closely related species, differences in the position of photophores can be subtle (Moser and Ahlstrom 1996).

Between 1982 and 1987, nearly 10000 specimens of meso-bathypelagic fish were caught along the coast of Baja California Sur, Mexico, by researchers from the Centro Interdisciplinario de Ciencias Marinas (CICIMARIPN), La Paz, B.C.S., Mexico (De La Cruz-Agüero and Galvan-Magaña 1992). Among all collected fishes, nearly one-third of the specimens belong to the family Myctophidae (nine genera and ten species). These fishes were recently the subject of maintenance and revision within the ichthyological collection (CI) of the CICIMARIPN. Among the lanternfishes, seven individuals exhibited an anomalous condition in the number and placement of photophores in their primary series.
Different types of anomalies and abnormalities in fishes are well documented (Dawson 1964, 1966, 1971, Dawson and Heal 1976). However, anomalies are scarcely or never reported among deep-sea fishes, and there are very few records concerning variation in the number and position of primary photophores (Davis et al. 2014, Klepadlo et al. 2014). Some lanternfishes have been found with slight variation in the diagnostic position of a single photophore (usually only one side of the body), which was not considered taxonomically significant and attributable to local factors (Wisner 1976, Hulley 1986, Klepadlo et al. 2014).

The anomalous patterns of light organs in specimens from the CI at the CICIMAR-IPN were discovered in the Mexican lampfish, Triphoturus mexicanus (Gilbert, 1890); the highseas lampfish, Triphoturus nigrescens (Brauer, 1904); and the popeye lampfish, Bolinichthys longipes (Brauer, 1906). This report provides descriptions and illustrations (Fig. 1) of these unusual and extraneous photophores.

Fishes were collected with an Isaacs-Kidd midwater trawl $\left(10 \mathrm{~m}\right.$ long, mouth opening $=8 \mathrm{~m}^{2}$, mesh size $=2.5$ $\times 1.25 \mathrm{~cm}$, and codend $=500 \mu \mathrm{m}$ mesh) during six cruises onboard the R/V El Puma, owned and operated by the Universidad Nacional Autonoma de Mexico (Table 1). These cruises covered both the Pacific and the Gulf of California coasts of Baja California Sur, Mexico $\left(27^{\circ} 09^{\prime} \mathrm{N}-23^{\circ} 19^{\prime} \mathrm{N}\right)$. All the collected specimens were fixed in $10 \%$ formalin,

\footnotetext{
* Correspondence: Dr. José De La Cruz-Agüero, Instituto Politécnico Nacional, Centro Interdisciplinario de Ciencias Marinas, Colección Ictiológica, Avenida Instituto Politécnico Nacional s/n, Colonia Playa Palo de Santa Rita, La Paz, Baja California Sur, 23096 México, phone: +52 612 1225344 , fax: +52 612 122 5322, e-mail: jcruz@ipn.mx.
} 
preserved in $70 \%$ isopropyl alcohol, and deposited and catalogued at the CI from the CICIMAR-IPN (voucher specimens in progressive lot numbers: CICIMAR-CI 2380 to 2700), where available upon request.

Standard abbreviations for primary light organs are cited as in Moser and Ahlstrom (1996): PLO, suprapectoral organ; PVO, subpectoral organ; VLO, supraventral organ; SAO, supralateral organ; AO, anal organs: (a) anterior, (p) posterior; INGL, infracaudal gland; VO, ventral organs; PO, thoracic organs (solid dot in Fig. 1A). Note that the series of photophores that are not discussed in this report are also not described herein (hollow dot in Fig. 1A). The description of photophore pattern per species, independently of the presence of anomalous light organs, is according to Wisner (1976):

Triphoturus mexicanus: $\mathrm{VO}_{2}$ and $\mathrm{VO}_{3}$ highly elevated and displaced forward to before verticals from $\mathrm{VO}_{1}$ and $\mathrm{VO}_{4}$, respectively. $\mathrm{PVO}_{1}$ well before vertical from $\mathrm{PVO}_{2}$.
PLO below but nearly touching the lateral line. The rest of upper photophores slightly above the lateral line. $\mathrm{PO}_{4}$ and $\mathrm{SAO}_{1-2}$ form a straight line that passes well above $\mathrm{VO}_{2}$ and $\mathrm{VO}_{3}$. SAO $\mathrm{S}_{1}$ well behind the vertical from $\mathrm{VO}_{4}$. The INGL is long and reaches or is near the end of the anal base.

Triphoturus nigrescens: Only $\mathrm{VO}_{2}$ elevated and displaced forward $\mathrm{VO}_{1}$. $\mathrm{PVO}_{1}$ almost directly below $\mathrm{PVO}_{2}$. Only upper photophores are below and touching the lateral line. $\mathrm{VO}_{2}$ about on the line through $\mathrm{PVO}_{2}, \mathrm{PO}_{4}$, and $\mathrm{SAO}_{1-2}$. The infracaudal luminous gland is short, ending far behind the end of the anal base.

Bolinichthys longipes: VLO touching or very near the lateral line. $\mathrm{VO}_{2}$ highly elevated, about on the level of the lower end of the pectoral base. Luminous scales at the base of dorsal- and anal-fin rays. INGL seldom reaches but never beyond the last AOp. VLO on the lateral line.

For this study, a thorough comparison of individual variation in the placement of photophores of anomalous
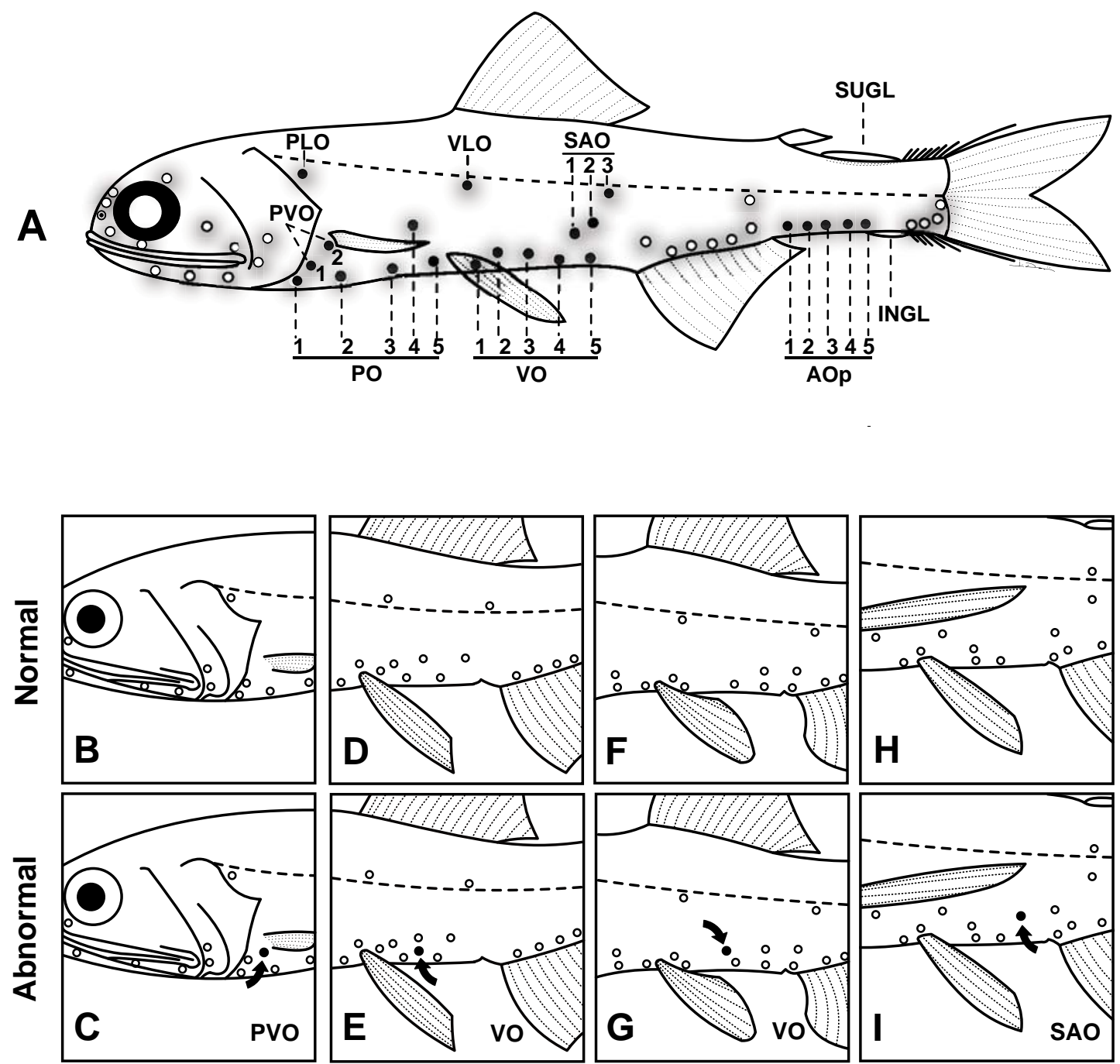

Fig. 1. Generalized photophore pattern for Myctophidae showing the location and abbreviations of the photophores discussed (solid dot); modified from Moser and Ahlstrom (1996) (A) and comparison of normal pattern and anomalies (indicated by an arrow) in number and positioning of photophores in three myctophid species (B-I): Triphoturus mexicanus (B-C and $\mathbf{D}-\mathbf{E})$, Triphoturus nigrescens $(\mathbf{F}-\mathbf{G})$, Bolinichthys longipes (H-I); Photophore terminology defined in the text 
Table 1

Anomalies in photophores of three lanternfish species: Triphoturus mexicanus, Bolinichthys longipes, and Triphoturus nigrescens

\begin{tabular}{|c|c|c|c|c|c|c|c|c|c|c|c|c|}
\hline \multirow{3}{*}{$\begin{array}{c}\text { Cruise } \\
\text { No. }\end{array}$} & \multirow{3}{*}{ Date } & \multirow{3}{*}{ Coordinates } & \multirow{3}{*}{ Species } & \multirow{3}{*}{$\begin{array}{c}\text { Voucher } \\
\text { specimens } \\
\text { No. }\end{array}$} & \multirow{3}{*}{$\begin{array}{l}\text { Specimens } \\
\text { per lot }\end{array}$} & \multirow{3}{*}{$\begin{array}{c}\text { TNVS } \\
\text { per species }\end{array}$} & \multicolumn{6}{|c|}{ Anomalies } \\
\hline & & & & & & & \multicolumn{2}{|c|}{$\begin{array}{l}\text { Supralateral } \\
\text { organ }\end{array}$} & \multicolumn{2}{|c|}{ Ventral organs } & \multicolumn{2}{|c|}{$\begin{array}{l}\text { Subpectoral } \\
\text { organ }\end{array}$} \\
\hline & & & & & & & $N$ & $\mathrm{SL}$ [mm] & $N$ & $\mathrm{SL}[\mathrm{mm}]$ & $N$ & $\mathrm{SL}[\mathrm{mm}]$ \\
\hline 8301 & 2 Mar 1983 & $\begin{array}{c}27^{\circ} 09^{\prime} \mathrm{N} \\
114^{\circ} 31^{\prime} \mathrm{W}\end{array}$ & T. mexicanus & 2458 & 43 & 1831 & & & & & 1 & 59 \\
\hline 8403 & 4 Apr 1984 & $\begin{array}{c}24^{\circ} 25^{\prime} \mathrm{N} \\
112^{\circ} 05^{\prime} \mathrm{W}\end{array}$ & B. longipes & 2585 & 1 & 51 & 1 & 27.5 & & & & \\
\hline 8403 & 7 Jun 1984 & $\begin{array}{c}23^{\circ} 22^{\prime} \mathrm{N} \\
111^{\circ} 58^{\prime} \mathrm{W}\end{array}$ & T. nigrescens & 2565 & 128 & 173 & & & 2 & $54.6-60$ & & \\
\hline 8707 & 11 Jul 1987 & $\begin{array}{c}26^{\circ} 31^{\prime} \mathrm{N} \\
114^{\circ} 34^{\prime} \mathrm{W}\end{array}$ & T. nigrescens & 2648 & 10 & 173 & & & 1 & 57.5 & & \\
\hline 8710 & 15 Oct 1987 & $\begin{array}{c}23^{\circ} 50^{\prime} \mathrm{N} \\
112^{\circ} 21^{\prime} \mathrm{W}\end{array}$ & T. mexicanus & 2520 & 65 & 1831 & & & 1 & 57 & & \\
\hline 8710 & 16 Oct 1987 & $\begin{array}{c}23^{\circ} 19^{\prime} \mathrm{N} \\
112^{\circ} 02^{\prime} \mathrm{W}\end{array}$ & T. mexicanus & 2518 & 64 & 1831 & & & 1 & 61.5 & & \\
\hline
\end{tabular}

Characteristics of fish and data collection ordered by date; TNVS per species = Total number of voucher specimens per species; Additional curatorial information of voucher specimens, available on the website of the Ichthyological Collection of the CICIMARIPN: http://coleccion.cicimar.ipn.mx.

fishes was made against the same species of myctophids deposited in the collection of the CICIMAR-IPN (see Table 1 for the number of specimens examined). These comparisonsweremadewithaWildMA7 stereomicroscope, contrasting the external morphology of photophores (i.e., number and placement). At the beginning of the study, a series of illustrations were made drawing the position of photophores' specific pattern according to diagnoses and taxonomic keys provided by Wisner (1976) and Hulley (1986). Measurements were made to the nearest $0.1 \mathrm{~mm}$. Standard length (SL) in $\mathrm{mm}$ is used throughout.

A total of 2055 specimens of the three myctophid species herein mentioned, including the lots containing anomalous fish, were studied. Cruises, dates, localities, lots per species, and the number of fishes collected and examined are listed in Table 1. Anomalies in the light organs were observed and detected only on the left side of seven specimens of these lanternfish specimens. These anomalies involve the number and location of photophores in the series VO (ventral organs), SAO (supralateral) and PVO (subpectoral). These abnormalities can be summarized as follows:

Triphoturus mexicanus. Three fishes (out of 172 specimens caught), 57.0-61.5 mm SL. PVO (one fish; CICIMAR-CI 2458): an additional photophore in the PVO series located between $\mathrm{PVO}_{2}$ and $\mathrm{PO}_{1}$, just below the pectoral fin (arrow Fig. 1C; normal pattern Fig. 1B). VO (two fishes; CICIMAR-CI 2518 and 2520): an additional photophore in VO series making six VO in total, located in both fishes on the left side of the body between $\mathrm{VO}_{1}$ and $\mathrm{VO}_{2}$ (see Fig. 1E; normal 1D). The rest of the primary series of photophores agree with the diagnosis of the species. No corresponding light organs were found on the right side.
Triphoturus nigrescens. Three fishes (out 138 specimens caught), 54.5- $60 \mathrm{~mm}$ SL. The additional luminous organ in VO (CICIMAR-CI 2565 and 2648) series for a total of six photophores (anomalous fish Fig. 1G; normal 1F). All lateral and ventrolateral series of photophores as in diagnosis. No corresponding light organs were found on the right side.

Bolinichthys longipes. One fish (out 1 fish collected), $27.5 \mathrm{~mm}$ SL. SAO (one fish; CICIMAR-CI 2585): additional photophore in SAO series, between $\mathrm{SAO}_{1}$ and $\mathrm{VO}_{3}$ forming nearly a straight line with $\mathrm{VO}_{1}$ and $\mathrm{SAO}_{1}$ (see Fig. 1I; normal 1H). All primary photophores agree with the description of the species. No corresponding light organs were found on the right side of the fish.

The many hypotheses advanced to explain the use or employment of bioluminescence in fishes (e.g., camouflage, defence, predation, communication, and reproduction) (Davis et al. 2016) serve to emphasize its multifarious roles among these species.

Recently, Davis et al. (2014) showed that lanternfishes are diversifying into new species at a more rapid rate than many other deep-sea fishes. This was explained by their lateral body photophores that exhibit species-specific properties that may play a functional role in species recognition-communication, and, as a result, contribute to genetic isolation, in contrast with the species that utilize bioluminescence in ways that would not promote isolation of populations (e.g., camouflage, predation).

In the presently reported case, the anomalous conditions appearing are not part of a subgroup since Hulley (1986) demonstrated that Triphoturus spp. has no subspecies, and no one has ever suggested that Bolinichthys spp. had any subspecies either. Also, Hulley (1986) has shown, for Triphoturus, that some photophores may vary slightly in position or they may be absent by net-abrasion during 
collection. However, no mention has been made on additional or supernumerary photophores. On the other hand, the possibility of sexual dimorphism is remote because lanternfishes sexual dimorphism has mostly been detected in the supra and infracaudal glands (Wisner 1976, Hulley 1986). Nevertheless, the seven specimens here described have abnormal photophore counts and positions for their respective species.

Supernumerary photophores have been found in the bright lanternfish, Myctophum phengodes (Lütken, 1892), displaced on the dorsal surface of the fish. This condition was considered for lanternfishes as "an unheard phenomenon" by Klepadlo et al. (2014), whose occurrence was regarded as very unusual, or infrequently discovered, to warrant a published record (Dr. P.A. Hulley indicated that in his database, from the 7624 specimens examined of Bolinichthys longipes, only one was supernumerary in $\mathrm{VO}_{2}$, and from the 12796 specimens examined of Triphoturus nigrescens only one had double photophore in position $\mathrm{SAO}_{2}$; pers. comm.).

Given limited identification of species-specific properties (e.g., communication) in the anomalous light organs discussed herein (i.e., PO series and VO series; see Davis et al. 2014: p. 1145), these anomalies, as suggested by Klepadlo et al. (2014), might be just an aberration, a genetic abnormality in the populations sampled, an indicator of local races (sensu Tamoykin and Trofimov 1986) or phenotypic plasticity in photophore position and orientation in the Myctophidae (P.A. Hulley, personal communication). Further studies and additional observations are necessary to assess the nature of these anomalies.

\section{ACKNOWLEDGEMENTS}

This work is dedicated to the memory of Peter J.P Whitehead, José Luis Castro-Aguirre, and Ellis Glazier, for their support to the CICIMAR-CI's work on deepsea fishes. Also to José Delacruz-Páez, who became an M.D. while this report was being written [02/II/2016]. Percy A. (Butch) Hulley gave advice on the manuscript. The author would like to thank William L. Smith for their valuable comments and suggestions, and to Mariana DiazSantana Iturríos for assistance in preparing the manuscript in English. Finally, I would also like to thank to the colleagues and technicians of the CI for their assistance, as well as the Comision de Operacion y Fomento de Actividades Academicas (COFAA-IPN), to Estímulo al Desempeño de los Investigadores (EDIIPN), and the Sistema Nacional de Investigadores (SNICONACyT) for the supports granted.

\section{REFERENCES}

Davis M.P., Holcroft N.I., Wiley E.O., Sparks J.S., Smith W.L. 2014. Species-specific bioluminescence facilitates speciation in the deep sea. Marine Biology 161 (5): 1139-1148.

DOI: $10.1007 / \mathrm{s} 00227-014-2406-\mathrm{x}$

Davis M.P., Sparks J.S., Smith W.L. 2016. Repeated and widespread evolution of bioluminescence in marine fishes. PLoS ONE 11 (6): e0155154.

DOI: $10.1371 /$ journal.pone.0155154

Dawson C.E. 1964. A bibliography of anomalies of fishes. Gulf Research Reports 1 (6): 308-399. DOI: $10.18785 /$ grr.0106.01

Dawson C.E. 1966. A bibliography of anomalies of fishes, Supplement 1. Gulf Research Reports 2 (2): 169-175. DOI: $10.18785 /$ grr.0202.03

Dawson C.E. 1971. A bibliography of anomalies of fishes, Supplement 2. Gulf Research Reports 3 (2): 215-239. DOI: $10.18785 /$ grr.0302.05

Dawson C.E., Heal E. 1976. A bibliography of anomalies of fishes: Supplement 3. Gulf Research Reports 5 (2): $35-41$. DOI: $10.18785 /$ grr.0502.05

De La Cruz-Agüero J., Galvan-Magaña F. 1992. Peces mesopelágicos de la costa occidental de Baja California Sur y del Golfo de California. Anales del Instituto de Ciencias del Mar y Limnología UNAM 19 (1): 25-31.

Froese R., Pauly D. (eds.) 2016. FishBase. [Version 06/2016] www.fishbase.org

Hulley P.A. 1986. A taxonomic review of the lanternfish genus Triphoturus Fraser-Brunner, 1949 (Myctophidae, Osteichthyes). Annals of the South African Museum 97 (4): 71-95.

Klepadlo C., Rochman C.M., Davison P. 2014. Report of Myctophum phengodes (Teleostei: Myctophidae) with extraneous photophores. Copeia 2014 (1): 106108 .

DOI: $10.1643 / \mathrm{ci}-13-062$

Moser H.G., Ahlstrom E.H. 1996. Myctophidae: Lanternfishes. Pp. 387-475. In: Moser H.G. (ed.) The early stages of fishes in the California Current region. CalCOFI Atlas 33. CalCOFI, La Jolla, CA, USA.

Nelson J.S., Grande T.C., Wilson M.V.H. 2016. Fishes of the World. 5th edn. Wiley, Hoboken, NJ, USA.

Tamoykin N.Y., Trofimov A.G. 1986. Identification and description of local races based on the arrangement and number of photophores in Myctophum nitidulum. Journal of Ichthyology 26 (3): 131-137.

Wisner R.L. 1976. The taxonomy and distribution of lanternfishes (family Myctophidae) of the eastern Pacific Ocean. Navy Oceanography Research Development Activity (NORDA) Report 3: 1-229.

Received: 12 July 2016

Accepted: 18 August 2016

Published electronically: 30 September 2016 